Лідери територіальних громад як атрактори ефективного суспільного розвитку

\author{
I. В. Письменний
}

Дніпропетровський регіональний інститут державного управління Національноі академії державного управління при Президентові України

УДК 332.075 (477)

DOI: $10.15421 / 15201733$

У статті сформульовано основний перелік здібностей, що обов’язково мають бути притаманні лідерам територіальних громад як атракторам ефективного суспільного розвитку. Обгрунтовано, що на голів територіальних громад, депутатський корпус, лідерів ініціативних груп громади покладається непросте завдання: на основі постійного соціального діалогу та партнерства 3 громадою забезпечити конструктивну суспільну самоорганізацію. За синергетичною методологією, фактично, ці особи мають стати атракторами ефективного суспільного розвитку. Проаналізовано окремі підходи до розуміння атрактора в сучасній науці. Стверджується, що майбутня система багато в чому залежить від лідерів, які спрямовують процес трансформації відповідної системи. Проаналізовані найважливіші аспекти лідерства, що $є$ актуальними на рівні територіальних громад. Обгрунтовано, що самоорганізація життєдіяльності в місцевому співтоваристві починається 3 утвердження принципів корпоратизму.

Ключові слова: самоорганізація; атрактор; територіальна громада; лідери; місцеве самоврядування; розвиток

\title{
Leaders of local communities as attractors of the efficient social development
}

I. V. Pysmennyy

Dnipropetrovsk Regional Institute of Public Administration of the National Academy of Public Administration under the President of Ukraine

The article formulates the basic list of abilities that leaders of local communities need to have as accractors of the effective social development. It is substantiated that the heads of territorial communities, deputies, leaders of initiative groups of the community are entrusted with not simple task, which is to provide constructive social self-organization, based on permanent social dialogue and partnership with the community. According to synergetics methodology these individuals have to become the attractors for the effective social development. The approaches to the understanding of an attractor in modern science are analyzed. The article affirms that the future system depends on leaders who direct transformation of the respective system. The most important aspects of leadership that are relevant at the level of local communities are analysed. It is substantiated that the self-organization of life in the local community begins with the establishment of the principles of corporatism.

Keywords: self-organization; attractor; local community leaders; local government; development

Цитування даної статті: Письменний І. В. Лідери територіальних громад як атрактори ефективного суспільного розвитку / І. В. Письменний // Аспекти публічного управління. - 2017. - Т. 5. - № 11. - С. 53-59. Citation of this article: Pysmennyy, I.V. (2017). Lidery terytorialnykh hromad yak atraktory efektyvnoho suspilnoho rozvytku [Leaders of local communities as attractors of the efficient social development]. Public administration aspects, 5 (11), 53-59.

Received: 27.10 .2017

Accepted: 03.11.2017 


\section{Лидеры территориальных общин как аттракторы эффективного общественного развития}

И. Письменный, Днепропетровский региональный институт государственного управления Национальной академии государственного управления при Президенте Украины

В статье сформулирован основной перечень способностей, которые обязательно должны быть присущи лидерам территориальных общин как аттракторам эффективного общественного развития. Обосновано, что на председателей территориальных общин, депутатский корпус, лидеров инициативных групп общества возлагается непростая задача: на основе постоянного социального диалога и партнерства с обществом обеспечить конструктивную общественную самоорганизацию. По синергетической методологии, фактически, эти лица должны стать аттракторами эффективного общественного развития. Проанализированы отдельные подходы к пониманию аттрактора в современной науке. Утверждается, что будущая система во многом зависит от лидеров, которые направляют процесс трансформации соответствующей системы. Проанализированы важнейшие аспекты лидерства, актуальные на уровне территориальных общин. Обосновано, что самоорганизация жизнедеятельности в местном сообществе начинается с утверждения принципов корпоративизма.

Ключевые слова: самоорганизация; аттрактор; территориальная община; лидеры; местное самоуправление; развитие

Постановка проблеми. В Україні розпочався процес децентралізації влади, що грунтується на Концепції реформування місцевого самоврядування та територіальної організації влади в Україні, проекті змін до Конституції України, Законах України «Про внесення змін до Бюджетного кодексу України щодо реформи міжбюджетних відносин» від 28 грудня 2014 року № 79, «Про добровільне об'єднання територіальних громад» від 5 лютого 2015 року № 157 та ін. Очевидно, що для вирішення масштабних i складних завдань розбудови реального місцевого самоврядування конче потрібні лідери, спроможні значно підвищити здатність мешканців територіальної громади діяти колективно та відповідально за результат спільних дій. Адже основним ресурсом громад є люди, поєднані спільним проживанням, цінностями та інтересами, працею та відпочинком, взаємодопомогою, особистими контактами, потребами, способом життя тощо.

Аналіз досліджень та публікацій. Питання дослідження феномену лідерства на різних рівнях публічного управління привертало увагу багатьох вчених. Зокрема, значний внесок у розвиток світоглядних і методологічних засад за цією проблематикою здійснено в роботах $\mathrm{H}$. Гончарук, С. Кравченка, Н. Липовської, А. Михненка, Т. Пахомової, С. Серьогіна, Ю. Сурміна та ін. Синергетичні аспекти публічного управління за цим напрямом дослідження висвітлюються в роботах В. Атаманчука, В. Бакуменка, Л. БойкоБойчук, Т. Бутирської, О. Валевського, В. Дрешпака, В. Слагіна, Ю. Комарової, І. Черленяка та інших учених.

Мета дослідження - сформулювати основний перелік здібностей, що обов'язково мають бути притаманні лідерам територіальних громад як атракторам ефективного суспільного розвитку.

Виклад основного матеріалу. У сучасних умовах державотворення на голів територіальних громад, депутатський корпус, лідерів ініціативних груп громади покладається непросте завдання: на основі постійного соціального діалогу та партнерства 3 громадою забезпечити конструктивну суспільну самоорганізацію. За синергетичною методологію, фактично, ці особи мають стати атракторами ефективного суспільного розвитку.

Слід зазначити, що розуміння атрактора в сучасній науці достатньо розмаїте. Зокрема, Ю. Комарова у своїх дослідженнях послуговується прийнятим у 
теорії самоорганізації терміном «атрактори порядку», який позначає наперед задані структури, що втілюють і детермінують потенційні стани системи, пристосовують самоорганізаційні процеси системи до тих зразків упорядкування, концентрованим описом яких і слугують. Атракторами політичного порядку можуть бути укорінені в суспільній свідомості культурні архетипи, міфи, політичні доктрини, ідеї, символи, а також інституційні суб'єкти політики, які їх уособлюють (суспільно-політичні лідери, партії, рухи тощо) [4, с. 99]. Л. Бойко-Бойчук, розглядаючи атрактор як атрибут, що застосовується для характеристики поведінки складних систем, приймає розуміння цього поняття як стан, до якого тяжіє (прямує) чи в якому перебуває система. I оскільки стан складної системи визначається багатьма факторами, тобто є багатовимірним, то й атрактор, на думку цієї авторки, слід вважати багатовимірним параметром, що складається 3 багатьох компонентів. Для соціально-політичних систем Л. Бойко-Бойчук визначає атрактор як фактор (групу факторів), що утримує систему в сталому стані. Складовими атрактора соціально-політичної системи дослідниця визначає:

1) соціально-політичну ідею (ідеї), на якій грунтується соціально-політична система;

2) харизматичного лідера (лідерів), які ініціюють втілення і підтримку існування соціально-політичної ідеї та відповідних соціально-політичних відносин;

3) структуру організації або інституції, що разом із лідером забезпечують втілення чи підтримку ідеології, функціонування та стійкого стану соціально-політичної системи;

4) параметри порядку, що являють собою певні обмеження поведінки як системи в цілому, так і іiі складових (частин, підсистем тощо) [2, с. 93].

На наш погляд, поняття атрактор тісно пов'язане саме 3 потенційними можливостями суспільства та процесами публічного управління в цьому суспільстві, що у своїй єдності та цілісності визначають шлях соціального розвитку, який може бути або еволюційним, або інволюційним. Адже процеси самоорганізації відбуваються в середовищі спільно $з$ іншими соціальними процесами, які мають протилежну спрямованість і можуть у певні періоди розвитку системи як домінувати над процесами самоорганізації, так і поступатися їм. При цьому якою саме буде майбутня система багато в чому залежить від лідерів, що спрямовують процес трансформації відповідної системи.

Дослідження лідерства, проведене «Європейським фондом управління якістю» презентувало модель виміру лідерства, що включає чотири базові елементи, a came:

1. Лідери розвивають місію, бачення, цінності й зразки для наслідування.

2. Лідери особисто приймають участь у створенні, впровадженні і постійному вдосконаленні організаційної системи управління.

3. Лідери активно співпрацюють 3 клієнтами, партнерами та представниками громадськості.

4. Лідери мотивують, підтримують підлеглих [6, с. 53].

Перелічені компоненти відповідають нашому баченню саме таких лідерів - атракторів суспільного розвитку, - потреба в яких на часі для ефективного розвитку місцевого самоврядування. Адже саме на рівні села або селища головні компоненти громадянського суспільства, громада й представницька влада, індивідуальні та колективні інтереси, права i свободи громадян, можуть отримати найповнішу реалізацію. Це обумовлено тим, що на місцевому рівні беруть початок усі суспільно-політичні процеси та закладаються підвалини взаємодії між людиною i державою. При цьому конструктивна суспільна самоорганізація має відбуватися шляхом широкого залучення громадян до процесу управління, що максимально 
можна забезпечити, передусім, на найближчому до людей рівні публічного адміністрування.

Для того, щоб стати ефективним лідером, необхідно встановлювати індивідуальні стосунки 3 кожним членом групи, враховувати його інтереси й потреби, надихати кожного окремо на досягнення результату. Лідерство - це характеристика поведінки людини, за якою йдуть інші. Не буває лідера без послідовників, без тих людей, котрі готові йти за ним. У такій ситуації між провідним керівником i підлеглими співробітниками найперше повинна виникнути якась спільність. Вони можуть бути об'єднані спільною метою, інтересами, внутрішніми цінностями, культурою, історичним минулим. Усе це викликає у людей спільне відчуття причетності та єдності, формує готовність до взаємодії і трудової активності. Соціальна психологія стверджує, 3 погляду послідовників, аби йти за кимось вони повинні відчувати свою цінність, важливість, значення для того, хто їх веде, хто ними управляє [3, с. 315].

Отже, лідери територіальних громад, насамперед, мають мотивувати мешканців до активної публічної діяльності щодо покращення умов існування та життєдіяльності громади. Для цього вони повинні розуміти проблеми громадян, виявляти щирість по відношенню до мешканців громади, всіляко сприяти формуванню відносин, заснованих на довірі один до одного. У громадянському суспільстві довіра населення формується шляхом, по-перше, забезпечення відкритості органів публічної влади задля розуміння громадянами сутності, цілей і завдань, що виникають у відповідній сфері життєдіяльності, по-друге, ефективного вирішення актуальних проблем населення 3 позиції представлення більшості інтересів громадян. Тому довіру громадян до публічної влади слід розглядати, по-перше, як один із основних чинників підвищення суспільного добробуту, а подруге, як рушійну силу ефективного сус- пільного розвитку.

Отже, самоорганізація життєдіяльності в місцевому співтоваристві починається 3 утвердження принципів корпоратизму, які тісно пов'язані 3 підтримкою малого й середнього підприємництва, створенням місцевих ринків, всезагальною зайнятістю населення, що породжує нові економічні джерела розвитку життєвих сил місцевого співтовариства. Сьогодні брати участь у місцевому самоврядуванні стає вигідно тоді, коли створюється розвинута та замкнута система соціально-фінансових інститутів, малого й середнього підприємництва, фінансово-промислових груп. Гроші населення в такому випадку починають працювати на розвиток території та приносити дивіденди. Чим заможнішим є населення, тим більше воно віддає вільних фінансових ресурсів на розвиток теритоpiï. Починає функціонувати ефективний механізм взаємодії, взаємодопомоги, кооперації [5, с. 130].

Слід погодитись із твердженням, що муніципальна влада формуватиметься та здійснюватиметься ефективно, якщо $\epsilon$ тісна взаємодія всередині місцевої популяції, внутрішню сторону життя, функціонування якої утворюють не тільки суспільна спрямованість, а й соціальнопсихологічні якості. Адже колектив - це організована група, члени якої об'єднанні спільними цілями, цінностями та завданнями діяльності, що $є$ значущими для всіх та кожного. В колективі існує багато видимих та невидимих, явних і прихованих, безпосередніх та опосередкованих зв'язків між окремими членами колективу. Колектив як організм немислимий без таких зв'язків.

Лише такі горизонтальні зв'язки та соціальні взаємодії можуть протистояти вертикалі натиску державної влади. Горизонтальні взаємодії формуються і сусідськими зв'язками, і мережею товариських відносин із колегами по роботі, і зусиллями громадських рухів та політичних партій. Велику роль у таких взаємодіях 
відіграють неурядові (недержавні) неприбуткові організації. Готовність допомогти сусідові, колезі, товаришеві, взагалі незнайомій людині має відкликатися у громадській свідомості надією, розрахунком на допомогу у вирішенні соціальних, економічних і навіть фізичних проблем [1, c. 356].

Для того, щоб підійти до створення такої спільноти, насамперед слід відмовитися від розуміння територіальної громади як простої математичної сукупності жителів відповідної адміністративно-територіальної одиниці. Це природна, свідомо сформована людська спільнота, самодостатня в своєму існуванні й розвиткові з погляду забезпечення фінансовими, природними ресурсами, соціально-політичної активності. Саме завдяки цій активності, а також муніципальній ініціативі така спільнота здатна на врядування своїми справами. Це також має суттєвий психологічний аспект, пов'язаний із формуванням у свідомості жителів населеного пункту відчуття належності до спільноти, яку утворює територіальна громада, виховання своєрідного місцевого патріотизму. Громада повинна викликати в серцях людей палку прихильність до себе, житель має бути прив'язаний до своєї громади не стільки тому, що він тут народився, скільки тому, що він убачає в громаді вільну й сильну корпоративну структуру, частиною якої він $є$ і яка заслуговує того, щоб докласти зусиль для участі в управлінні нею. Лише усвідомлення цього моменту сприятиме активізації участі членів територіальної громади в здійсненні місцевого самоврядування, у безпосередньому вирішенні питань місцевого значення, а тим самим сприятиме розвитку муніципальної влади [1, с. 363$]$.

Фактично кожен мешканець громади має відчути свою суб'єктність у вирішенні питань місцевого значення та формуванні бажаного середовища, що характеризується пріоритетом суспільних цінностей і здатністю до ефективної суспільної взаємодії. За таких умов кон- структивної суспільної самоорганізації та довіри до лідерів місцевої влади відбувається добровільне взяття на себе членами територіальної громади зобов'язань щодо здійснення суспільних функцій, що у свою чергу забезпечує оперативність реалізації відповідних рішень та посилює відповідальність за їх результат.

У свою чергу лідери територіальних громад як атрактори ефективного суспільного розвитку повинні вміти в мінливому середовищі мислити масштабно та бути готовими до прийняття оптимальних рішень в умовах середовища, яке надзвичайно динамічно змінюється. Однією 3 моделей (із акцентуванням уваги на керуванні змінами) є модель адаптаційного лідерства. Згідно з моделлю, розробленою дослідниками Гарвардського університету, лідерство спрямовано на зміну діяльності організації (територіальної громади) для реагування на зміни та складні політичні явища. Адаптація - динамічний процес, який передбачає вплив на оточення, а це оточення, у свою чергу, змінюе особистість. Адаптаційне лідерство має за мету розвиток інтелігентних, моральних, проективних та динамічних відносин із оточенням, а не пристосування до них. Роль лідерства полягає в умінні визначити предмет змін та спланувати дії, необхідні для досягнення поставлених цілей [3, с. 314]

I ще один важливий чинник відзначають учені для спільного просування вперед лідера та його послідовників. У них має бути запал, інтерес досягати результату, рухатися до поставленої мети. Цей інтерес і бажання рухатися вперед до наміченої мети повинен пробуджувати й підтримувати у своїх соратниках лідер [3, c. 315].

Висновки. Очевидно, що для того, щоб реалізувати таку ідеальну модель взаємовідносин на рівні територіальної громади, іiі лідерам, окрім наявності організаторського досвіду та професійної компетентності, необхідно мати певні особливі навички й уміння ефектив- 
ного управління суспільною енергією та спрямування iï на корисний результат. Спробуємо сформулювати основний перелік таких здібностей, що обов'язково має бути притаманним лідерам - атракторам ефективного суспільного розвитку. На наш погляд, до них належать:

- вміння проектувати картину майбутнього територіальної громади, яка одночасно оптимістична й досяжна, а також заохочує громадян до досягнення високого рівня очікуваних результатів;

- уміння об'єктивно аналізувати стан організації та самоорганізації в громаді i детермінувати потенційну динаміку i розвитку;

- вміння синтезувати ключові проблеми та перспективні можливості подальшої життєдіяльності громади в процесі спільної з усіма членами громади розробки програми стратегічного розвитку;

- вміння ефективно розміщувати та використовувати ресурси територіальної громади (людські, матеріальні, фінансові та ін.);

- уміння виявляти зони підвищеної вірогідності виникнення кризових ситуацій в процесі реалізації відповідних напрямів програми стратегічного розвитку громади;
- вміння налагодити та усіляко сприяти розвитку горизонтальних зв'язків серед членів територіальної громади;

- вміння забезпечувати ефективну взаємодію усіх зацікавлених соціальних суб'єктів та об'єктів територіальної громади на принципах кооперативності;

- вміння впроваджувати інноваційні зміни, що узгоджені із сучасними тенденціями суспільного розвитку та $є$ зрозумілими для членів територіальної громади;

- вміння критично аналізувати кінцеву ефективність прийнятих рішень, а також стиль та методи власної організац ійно-управлінської діяльності.

Окрім зазначених умінь, перелік яких не $є$ остаточним, цілком очевидно, що лідери мають бути високоморальними особистостями, які прикладом власної поведінки спонукають мешканців громади діяти чесно, відкрито та в інтересах суспільної життєдіяльності. На наш погляд, завдяки формуванню критичної маси таких лідерів - аттракторів ефективного суспільного розвитку в Україні все більше буде 3'являтися самодостатніх, конкурентоспроможних громад, що здатні якісно без допомоги держави надавати послуги громадянам.

\section{БІБЛІОГРАФІЧНІ ПОСИЛАННЯ}

1. Антоненко В. О. Актуальні проблеми становлення та розвитку місцевого самоврядування в Україні : кол. моногр. / В. О. Антоненко, М. О. Баймуратов, О. В. Батанов [та ін.]; за ред. В. В. Кравченка, М. О. Баймуратова, О. В. Батанова. - Київ : Атіка, 2007. - 864 с.

2. Бойко-Бойчук Л. Методика синергетичного аналізу соціально-політичних систем (теоретичний аспект) / Л. Бойко-Бойчук // Людина і політика. - 2004. - № 4. - С. 92-105.

3. Державне управління: підручник: у 2 т. / Нац. акад. держ. упр. при Президентові України; ред. кол. : Ю. В. Ковбасюк (голова), К. О. Ващенко (заст. голови), Ю. П. Сурмін (заст. голови) [та ін.]. Київ ; Дніпро : НАДУ, 2012. - Т. 1. - 564 с.

4. Комарова Ю. Деякі аспекти аналізу структурної самоорганізації політичної системи / Ю. Комарова // Політ. менедж. - 2005. - № 1. - С. 97-112.

5. Лазор О. Д. Місцеве управління: поняття, терміни, визначення: словн.-довідник / О. Д. Лазор, О. Я. Лазор. - Київ : Дакор, 2004. - 336 с.

6. Управлінська еліта як чинник суспільного розвитку : монографія / за ред. А. М. Михненка. Київ : НАДУ, 2012. - 175 с. 


\section{REFERENCES:}

1. Antonenko, V.O., Baimuratov, M.O., \& Batanov, O.V. et al. (2007). Aktualni problemy stanovlennia ta rozvytku mistsevoho samovriaduvannia $v$ Ukraini [Actual problems of the formation and development of local self-government in Ukraine]. Kyiv: Atika [in Ukrainian].

2. Boiko-Boichuk, L. (2004). Metodyka synerhetychnoho analizu sotsialno-politychnykh system (teoretychnyi aspekt) [Method of synergistic analysis of socio-political systems (theoretical aspect)]. Liudyna i polityka - Man and politics, 4, 92-105 [in Ukrainian].

3. Kovbasiuk, Yu.V., Vashchenko, K.O., \& Surmin, Yu. P. et al. (Eds.). (2012). Derzhavne upravlinnia: pidruchnyk [Public administration]. (Vols. 1-2). Kyiv, Dnipro: NADU [in Ukrainian].

4. Komarova, Yu. (2005). Deiaki aspekty analizu strukturnoi samoorhanizatsii politychnoi systemy [Some aspects of the analysis of the structural self-organization of the political system]. Politychnyi menedzhment - Political management, 1, 97-112 [in Ukrainian].

5. Lazor, O.D., \& Lazor, O.Ya. (2004). Mistseve upravlinnia: poniattia, terminy, vyznachennia [Local management: concepts, terms, definitions]. Kyiv: Dakor [in Ukrainian].

6. Mykhnenko, A.M. (Eds.). (2012). Upravlinska elita yak chynnyk suspilnoho rozvytku [Management elite as a factor in social development]. Kyiv: NADU [in Ukrainian].

Письленний Ігор Володимирович - доктор наук, професор

Дніпропетровський регіональний інститут державного управління Національноӥ акаделії державного управління при Президентові України Адреса: 49044, м. Дніпро, вул. Гоголя, 29

E-mail:makxim_ip@mail.com

Pysmennyy Igor V. - Full Prof. Dr.

Dnipropetrovsk Regional Institute of Public Administration of the National Academy of Public Administration under the President of Ukraine

Address: 29, Hoholia str., Dnipro, 49044, Ukraine

E-mail:makxim_ip@mail.com 